\title{
Anteseden dari Pengungkapan Enterprise Risk Management pada Perusahaan yang Terdaftar di Indeks LQ45
}

\author{
Keny Prasetyo Rini ${ }^{1}$, Tuti Zakiyah ${ }^{2}$ \\ Sekolah Tinggi Ilmu Ekonomi Putra Bangsa \\ Email:kenirini14@gmail.com ${ }^{1,}$ tutizakiyah@gmail.com ${ }^{2}$
}

Abstract: : The purpose of this research is to determine te influences of independent commissioners, auditor reputation, risk management committee, leverage and firm size on enterprise risk management disclosure in index LQ45 companies listed in the 2016-2018. The samplimg method in this research is purposive sampling with 81 companies as population and 27 companies as samples. The ERM practice is measured based on ERM index, which considers the eight dimension of ERM by COSO framework. The results of simultaneous regression analysis show that the variables of independent commissioner, auditor reoutation, risk manegement committee, leverage and firm size have positif effects on the enterprise risk management disclosure. Partial testing shows that variabel of independent commissioner, risk management commite and firm size does not effect enterprise risk management disclosure. Auditor reputation and risk management committee have positive effects on enterprise risk management.

Keywords : Enterprise Risk Managemnt, Independent Commissioner, Auditor Reputation, Risk Management Committee, Leverage and Firm Size.

Abstrak :Tujuan penelitia ini adalah untuk mengetahui pengaruh komisaris independen, reputasi auditor, risk management committee, leverage dan ukuran perusahaan terhadap pengungkapan enterprise risk management (Studi Kasus pada perusahaan yang terdaftar di Indeks LQ45 tahun 2016-2018. Penelitian ini menggunakan metode purposive sampling dengan jumlah populasi sebesar 81 perusahaan dan sampel sebesar 27 perusahaan. Penerapan ERM diukur berdasarkan indeks ERM dengan mempertimbangkan delapan dimensi COSO ERM framework. Hasil pengujian simultan menunjukkan bahwa komisaris independen, reputasi auditor, RMC, leverage dan ukuran perusahaan berpengaruh positif terhadap pengungkapan ERM. Pengujian parsial menunjukan komisaris independen, RMC, dan ukuran perusahaan tidak berpengaruh terhadap pengungkapan ERM. Sedangkan, Reputasi auditor dan leverage berpengaruh positif terhadap pengungkapan ERM.

Kata kunci: Enterprise risk management, komisaris independe, reputasi auditor, risk management committee, leverge dan ukuran perusahaan.

\section{A. Pendahuluan}

Bursa Efek Indonesia (BEI) merupakan suatu lembaga pasar modal yang merupakan gabungan dari Bursa Efek Jakarta dan Bursa Efek Surabaya. Pasar modal merupakan salah satu sumber pembiayaan eksternal bagi dunia bisnis, serta sebagai wahana investasi bagi investor dalam maupun luar negeri. Pasar modal sangat sensitif terhadap peristiwa atau informasi yang beredar disekitarnya. Peristiwa atau informasi dapat memotivasi investor untuk beraksi apakah menjual atau membeli saham.

Indeks LQ45 merupakan salah satu indeks di Bursa Efek Indonesia (BEI), dimana saham tersebut lebih diminati karena dianggap stabil, risikonya kecil dan memiliki likuiditas serta kapitalisasi pasar yang tinggi. Tingginya kepercayaan publik terhadap 
saham indeks LQ45 harus diiringi dengan pengelolaan risiko yang memadai. ${ }^{1}$ Berbagai peristiwa ekonomi baik global maupun dalam negeri turut mewarnai pergerakan LQ45. Salah satunya sentimen negatif dari Amerika Serikat (AS), The Fed yang menaikan suku bunganya hingga $4 \mathrm{x}$ memberi tekanan bagi indeks tersebut. Permasalahannya, kenaikan suku bunga the fed diikuti oleh Bank Indonesia (BI) yang ingin ahead the curve agar terhidar dari risiko capital flight yang dapat menekan rupiah. Bank Indonesia (BI) yang menaikan suku bunga acuannya sebanyak 175 basis poin pada tahun 2018, menjadi beban tersendiri bagi emiten bursa karena bunga utang kian membesar. Bagai mendapat tekanan dari berbagai sisi, rupiah yang melemah terhadap dolar AS juga menjadi kekhawatiran tersendiri. Rupiah sempat menyentuh level tertinggi tahun 2018 di Rp. 15.265 pada Kamis (11/10/2018). Meskipun dipenghujung tahun 2018 berhasil menipiskan perlemahan dengan hanya terkoreksi 7,3\% di level Rp. 14.555/US. ${ }^{2}$

\section{Gambar 1}

Pergerakan Harga Saham Indeks LQ45

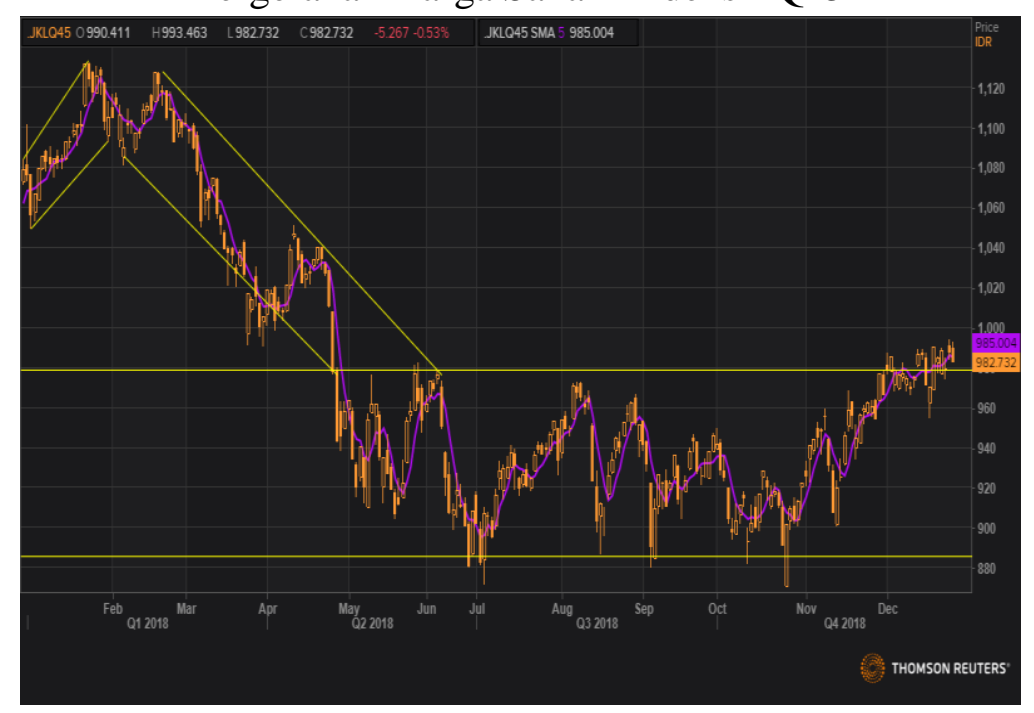

Sumber: www.cnbcindonesia.com

Pergerakan LQ45 ini cenderung melemah. Meskipun pada awalnya sempat mengalami kenaikan hingga menyentuh level tertinggi di 1.132 (24/01/2018). Pada awal Juli, LQ45 terus tertekan hingga menyentuh level terendahnya di 871 (-23\%). Sejak penurunan tersebut, tren pergerakan cenderung membaik dan bergerak mendatar (sindeways) dengan penghalang kenaikan (resistance) di level 980 dan penahan penurunannya (support) di level 885. Dalam jangka pendek LQ45 masih berpotensi melemah karena bergerak didekat level resistance. Potensi pelemahan juga tercermin dari posisinya yang bergerak dibawah garis rata-rata harganya selama lima hari (moving average.$^{3}$

Manajemen risiko perusahaan atau Enterprise Risk Management (ERM) merupakan suatu strategi yang digunakan untuk mengevaluasi dan mengelolah semua risiko dalam perusahaan. Penerapan manajemen risiko erat kaitannya dengan pelaksanaan good corporate governance, yaitu prinsip transparansi yang menuntut diterapkannya enterprise risk management. Corporate governance merupakan konsep yang didasarkan pada teori

1 CNBC Indonesia, “Market Data," last modified 2018, accessed October 11, 2018, https://www.cnbcindonesia.com/market-data.

${ }^{2}$ Ibid. 
keagenan dan diharapkan dapat berfungsi sebagai alat untuk memberikan keyakinan kepada para investor bahwa mereka menerima return atas dana yang telah mereka investasikan. Komite Nasional Kebijakan Governance (2012) mendefinisikan corporate governance dengan pencapaian keberhasilan usaha dan juga cara untuk memantau kinerja pencapaian sasaran keberhasilan usaha tersebut. Corporate Governance menjelaskan distribusi hak-hak dan tanggung jawab dari masing-masing pihak yang terlibat dalam sebuah bisnis, yaitu antara lain dewan komisaris dan direksi, manajer, pemegang saham, auditor serta pihak-pihak lain yang terkait sebagai stakeholders. ${ }^{4}$

Jurnal ini membahas mengenai Enterprise Risk Management (ERM), reputasi auditor, risk management committee, leverage, ukuran perusahaan berpengaruh secara simultan terhadap Enterprise Risk Management (ERM) pada perusahaan yang terdaftar di Indeks LQ45.

\section{B. Metodologi Penelitian}

\section{Model Empiris}

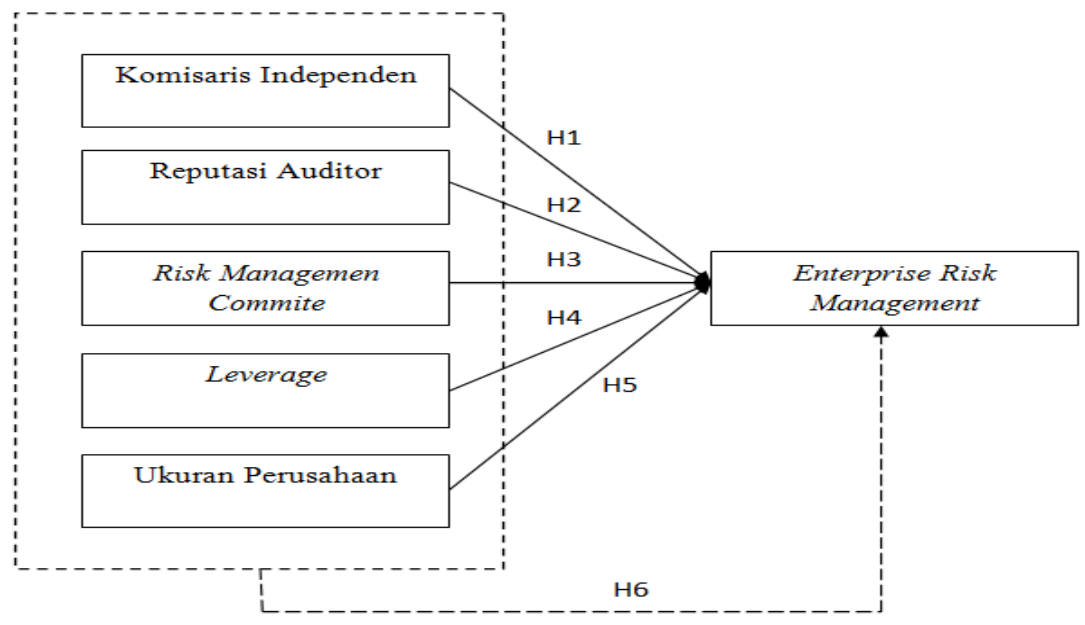

\section{Hipotesis}

Gambar 2. Model Empiris

Hipotesis dapat diartikan sebagai suatu jawaban yang bersifat sementara terhadap permasalahan penelitian, sampai terbukti melalui data yang terkumpul, mengacu pada landasan teori yang ada.

H1 : Komisaris Independen berpengaruh positif terhadap Enterprise Risk Management.

H2 : Reputasi Auditor berpengaruh positif terhadap Enterprise Risk Management.

H3 : Risk Management Committee berpengaruh positif terhadap Enterprise Risk Management.

H4 : Leverage berpengaruh positif terhadap Enterprise Risk Management.

H5 : Ukuran Perusahaan berpengaruh positif terhadap Enterprise Risk Management.

\section{Objek Penelitian}

Objek penelitian ini adalah Komisaris independen, reputasi auditor, risk manajemen committee, leverage, ukuran perusahaan dan enterprise risk management (ERM).

${ }^{4}$ Alijoyo, Antonius, dkk, Pedoman Penerapan Manajemen Risko Berbasis Governance (Jakarta: Alijoyo, Antonius, dkk, (2012) Komite Nasional Kebijakan Governance, 2012). h.26. 


\section{Subjek Penelitian}

Subjek pada penelitian ini adalah perusahaan-perusahaan yang tergabung dalam indeks LQ45 di Bursa Efek Indonesia.

\section{Definisi Operasional Variabel}

1) Komisaris Independen

Menurut Rustiarini, 2012 Komisaris menurut Komite Nasional Kebijakan Governance adalah Komisaris yang tidak berasal dari pihak terafiliasi, yang dimaksud dengan terafiliasi adalah pihak yang mempunyai hubungan bisnis dan kekeluargaan dengan pemegang saham pengendali, anggota direksi dan dewan komisaris lain, serta dengan perusahaan itu sendiri. Menurut Rustiarini, (2012) pengukuran komisaris independen yaitu jumlah komisaris independen dibandingkan dengan jumlah seluruh anggota dewan komisaris. ${ }^{5}$

$$
\mathrm{KI}=\frac{\text { Jumlah Komisaris Independen }}{\text { Jumlah anggota dewan Komisaris }} \times 100 \%
$$

2) Reputasi Auditor

Auditor big four dapat memberikan panduan mengenai praktek Good Corporate Governance, membantu internal auditor dalam mengevaluasi dan meningkatkan efektivitas manajemen risiko sehingga meningkatkan kualitas penilaian dan pengawasan risiko perusahaan. Menurut Rustiarini ${ }^{6}$ Penelitian ini menggunakan audit big four sebagai proksi dari reputasi auditor. (Rustiarini, 2012) pengukuran variabel dengan menggunakan variabel dummy yaitu apabila perusahaan menggunakan KAP audit big four dalam mengaudit laporan keuangan maka diberi nilai 1 dan sebaliknya diberi nilai 0 .

\section{3) Risk Management Committee}

Komite Nasional Kebijakan Governance ${ }^{7}$ menjelaskan Risk Management Committee sebagai organ dewan komisaris yang membantu melakukan pengawasan dan pemantauan pelaksanaan penerapan manajemen risiko pada perusahaan. Terdapat dua tipe komite manajemen risiko yaitu komite manajemen risiko yang berdiri sendiri dan komite manajemen risiko yang diintegrasikan dengan komite audit. Menurut Rustiarini ${ }^{8}$ RMC dalam penelitian ini diukur dengan menggunakan variabel dummy yaitu apabila perusahaan memiliki RMC tergabung dengan komite audit maupun terpisah dari komite audit diberi nilai 1 dan sebaliknya diberi nilai 0 .

\footnotetext{
${ }^{5}$ Ni Wayan. Rustiarini, “Corporate Governance, Konsentrasi Kepemilikan Dan Pengungkapan Enterprise Risk Management,” Journal manajemen keuangan, akuntabilitas 12, no. 2 (2012): 279 - 298.

${ }^{6}$ Ibid.

${ }^{7}$ Komite Nasional Kebijakan Governance, Pedoman Penerapan Manajemen Risiko Berbasis Governance (Jakarta, 2011), http://www.knkg-indonesia.org/.

${ }^{8}$ Rustiarini, "Corporate Governance, Konsentrasi Kepemilikan Dan Pengungkapan Enterprise Risk Management.” h. 4
} 


\section{4) Leverage}

Leverage ratio atau rasio solvabilitas menurut Kasmir ${ }^{9}$ merupakan rasio yang digunakan untuk mengukur sejauh mana aktiva perusahaan dibiayai dengan utang. Pada penelitian ini rasio yang digunakan untuk mengukur leverage adalah debt to asset ratio (DAR). Menurut Kasmir ${ }^{10}$ debt to asset ratio adalah rasio yang digunakan untuk menilai utang dengan Asset.

$$
\text { Debt to Assets Ratio }(D A R)=\frac{\text { Total Utang }}{\text { Total Aseset }}
$$

5) Ukuran Perusahaan

Ukuran perusahaan (firm size) adalah suatu ukuran yang menunjukkan besar kecilnya suatu perusahaan, antara lain total penjualan, rata-rata tingkat penjualan, dan total aktiva ${ }^{11}$. Pada penelitian ini, total asset menjadi pengukur ukuran perusahaan, karena asset berguna sebagai alat operasional perusahaan yang akan menunjukkan kinerja perusahaan dalam memperoleh keuntungan dari kegiatan operasional perusahaan. Dan variable ini diukur dengan Ln total Asset.

\section{Hasil dan Pembahasan}

\section{Pengertian}

Agency adalah keterkaitan hubungan antara dua pihak yang mana pihak satu sering disebut agen, yaitu pihak yang diberikan kewenangan untuk melakukan perbuatan untuk dan atas nama serta di bawah pengawasan pihak lain, yaitu parcipal. Parcipal adalah pihak yang memberikan kewenangan pada aagen untuk melakukan tindakan tertentu serta melakukan pengawasan tindakan agen, sedangkan pihak yang melakukan transaksi dengan agen disebut dengan third party. Dengan demikian, dalam agency terdapat tiga pihak utama, yaitu principal, agent, dan third party. ${ }^{12}$

Menurut Brigham dan Houston (2001) isyarat atau signal adalah suatu tindakan yang diambil perusahaan untuk memberi petunjuk bagi investor tentang bagaimana manajemen memandang prospek perusahaan. Sinyal ini berupa informasi mengenai apa yang sudah dilakukan oleh manajemen untuk merealisasikan keinginan pemilik. Sinyal dapat berupa informasi yang menyatakan bahwa perusahaan tersebut lebih baik daripada perusahaan lain. Informasi yang dikeluarkan oleh perusahaan merupakan hal yang penting, karena pengaruhnya terhadap keputusan investasi pihak diluar perusahaan. $^{13}$

Kemudian Definisi Stakeholder menurut Freeman dan Mc Vea adalah setiap kelompok atau individu yang dapat mempengaruhi atau dipengaruhi oleh pencapaian tujuan organisasi. ${ }^{14}$ Teori stakeholder adalah teori yang menggambarkan kepada pihak

\footnotetext{
${ }^{9}$ Kasmir, Pengantar Manajemen Keuangan, 2nd ed. (Jakarta: Prenadamedia Grup, 2016).

${ }^{10}$ Ibid. h. 157

${ }^{11}$ Widjaja Azwar, Perencanaan Sebagai Fungsi Manajemen (Jakarta: PT. Rineka Cipta., 2009). h. 25

12 Budi Setiawan, "Pengaruh Independensi, Kualitas Audit Dan Mekanisme Corporate Governance Terhadap Integritas Laporan Keuangan Perusahaan Manufaktur Di Bursa Efek Indonesia Tahun 2008-2012," Jom FEKON 2, no. 2 (2015): 1-15.

${ }^{13}$ Brigham dan Houston, Manajemen Keuangan, Edisi Kedelapan, 8th ed. (Jakarta: Erlangga, 2001). h. 23

${ }^{14}$ McVea Freeman, R.F dan J, A Stakeholder Approach to Strategic Management (lose Angeles: Sage Publications, 2001). h. 105
} 
mana saja perusahaan bertanggungjawab. Perusahaan harus menjaga hubungan dengan stakeholdernya dengan mengakomodasi keinginan dan kebutuhan stakeholder-nya, terutama stakeholder yang mempunyai power terhadap ketersediaan sumber data yang digunakan untuk aktivitas operasional perusahaan, misal tenaga kerja, pasar atas produk perusahaan dan lain-lain.

Committee of Sponsoring Organizations of the Treadway Commission COSO 2004 mendefinisikan Enterprise Risk Management (ERM) sebagai Process, effected by an entity's board of directors, management, and other personnel, applied in strategy setting and across the enterprise, designed to identify potential events that may affect the entity, and manage risks to be with in its risk appetite to provide reasonable assurance regarding the achievement of entity objectives . ${ }^{15}$

Definisi ini mencerminkan konsep dasar bahwa manajemen risiko perusahaan adalah Sebuah proses yang sedang berlangsung dan mengalir melalui suatu entitas; Sebagai akibat oleh setiap orang dalam tingkat organisasi; Diterapkan dalam pengaturan strategi; Diterapkan diseluruh perusahaan, pada setiap tingkat dan unit, dan termasuk dalam meriview pengambilan tingkat entitas portofolio yang berisiko; Dirancang untuk mengenali peluang kejadian yang jika terjadi akan mempengaruhi jalannya udaha dan organisasi; Mampu untuk memberikan keyakinan memadai kepada manajemen entitas dan dewan direksi; Diarahkan untuk mencapai tujuan.

Selanjutnya komisaris independen menurut Komite Nasional Kebijakan Governance adalah komisaris yang tidak berasal dari pihak terafiliasi, yang dimaksud dengan terafiliasi adalah pihak yang mempunyai hubungan bisnis dan kekeluargaan dengan pemegang saham pengendali, anggota direksi dan dewan komisaris lain, serta dengan perusahaan itu sendiri. ${ }^{16}$

Audit adalah satu alat ukur untuk mengevaluasi perusahaan terhadap komitmennya untuk menerapkan sistem secara konsisten. Proses audit dalam perusahaan dilakukan oleh auditor internal dan auditor eksternal. Reputasi Auditor merupakan dimana auditor bertanggung jawab untuk tetap menjaga kepercayaan publik dan menjaga nama baik auditor sendiri serta KAP tempat auditor tersebut bekerja dengan mengeluarkan opini yang sesuai dengan keadaan perusahaan yang sebenarnya.$^{17}$

Risk Management Committee merupakan mekanisme pengawas risiko yang penting bagi perusahaan. ${ }^{18}$ Menurut Subramaniam terdapat dua tipe komite manajemen risiko yaitu komite manajemen risiko yang berdiri sendiri dan komite manajemen risiko yang diintegrasikan dengan komite audit. Tujuan pembentukan komite audit adalah memastikan laporan keuangan yang dikeluarkan tidak menyesatkan dan sesuai dengan praktik akuntansi yang berlaku umum, memastikan bahwa internal kontrolnya memadai, menindak lanjut dugaan terhadap adanya

${ }^{15}$ Committee of Sponsoring Organization of the Treadway Commission (COSO), "Internal ControlIntegred Framework," accessed October 15, 2019, https://www.coso.org/Pages/ic.aspx.

${ }^{16}$ Alijoyo, Antonius, dkk, Pedoman Penerapan Manajemen Risko Berbasis Governance. h. 30

${ }^{17}$ Komang Verdiana and I Utama, "Pengaruh Reputasi Auditor, Disclosure, Audit Client Tenure Pada Kemungkinan Pengungkapan Opini Audit Going Concern," E-Jurnal Akuntansi 5, no. 3 (2013): 530-543.

${ }^{18}$ Putri Andarini and Indira Januarti, "Hubungan Karakteristik Dewan Komisaris Dan Perusahaan Terhadap Keberadaan Komite Manajemen Risiko Pada Perusahaan Go Public Indonesia,” Jurnal Akuntansi dan Keuangan Indonesia 9, no. 1 (2012): 83-99. 
penyimpangan yang material dibidang keuangan dan impliasi hukumnya dan merekomendasikan seleksi auditor eksternal. ${ }^{19}$

Leverage merupakan rasio yang digunakan untuk mengukur sejauh mana aktiva perusahaan dibiayai dengan utang. ${ }^{20}$ Rasio solvabilitas atau rasio struktur modal atau rasio leverage merupakan rasio yang menggambarkan kemampuan perusahaan dalam memenuhi seluruh kewajibannya. ${ }^{21}$

Ukuran perusahaan (firm size) adalah suatu ukuran yang menunjukkan besar kecilnya suatu perusahaan, antara lain total penjualan, rata-rata tingkat penjualan, dan total aktiva. ${ }^{22}$ Menurut Riyanto ukuran perusahaan adalah besar kecilnya perusahaan dilihat dari besarnya nilai equity, nilai penjualan atau nilai aktiva. ${ }^{23}$

2. Komisaris independen, reputasi auditor, risk manajemen committee, leverage, ukuran perusahaan dan enterprise risk management (ERM).

Dibawah ini di sajikan berdasarkan hasil pengelolaan data.

Tabel 1. Hasil Statistik Deskriptif

\begin{tabular}{cccccc}
\hline & $\mathrm{N}$ & Minimum & Maximum & Mean & Std. Deviation \\
\hline KI & 81 & .17 & .83 & .4129 & .13629 \\
RA & 81 & .00 & 1.00 & .8519 & .35746 \\
RMC & 81 & .00 & 1.00 & .6049 & .49191 \\
DAR & 81 & .07 & .83 & .4283 & .18760 \\
SIZE & 81 & 29.06 & 34.33 & 31.2720 & 1.17891 \\
ERM & 81 & .40 & .81 & .6664 & .11028 \\
Valid N (listwise) & 81 & & & & \\
\multicolumn{5}{l}{ Sumber : Output SPSS 21, 2020 }
\end{tabular}

Dari tabel IV-1 di atas menunjukkan bahwa jumlah sampel dalam penelitian $(\mathrm{N})$ adalah 81. Variabel komisaris independen (KI) memiliki nimai minimum sebesar 0,17 yang diperoleh dari PT Pembangunan Perumahan (Persero) Tbk, yang memiliki 1 komisaris independen dari 6 dewan komisaris yang ada dalam perusahaan pada tahun 2018. Sedangkan nilai maksimum sebesar 0,83 diperoleh dari PT Lippo Karawaci Tbk, dengan 5 komisaris independen dari 6 dewan komisaris yang ada dalam perusahaan pada tahun 2016. Nilai rata-rata komisaris independen sebesar 0,4129 atau 41,29\% yang menunjukkan bahwa perusahaan yang menjadi sampel dalam penelitian ini telah memenuhi ketentuan yang disyaratkan oleh Bapepam untuk jumlah komisaris independen yaitu sekurang-kurangnya $30 \%$ dari seluruh jumlah anggota komisaris dan nilai standar deviasi komisaris independen adalah sebesar 0,13629.

Variabel independen reputasi auditor menggunakan ukuran kantor akuntan publik (KAP) atau skala auditor dengan menggunakan variabel dummy yaitu nilai satu untuk perusahaan yang diaudit oleh KAP Big Four dan nilai nol untuk perusahaan yang

\footnotetext{
${ }^{19}$ Haidir Fitra Siagian, "Pengaruh Dan Efektivitas Penggunaan Media Sosial Sebagai Saluran Komunikasi Politik Dalam Membentuk Opini Publik," Al-Khitabah 11 (2015): 17-26.

${ }^{20}$ Kasmir, Pengantar Manajemen Keuangan. h. 50

${ }^{21}$ Ibid. h. 55

22 halwati widyawati, "Pengaruh Corporate Governance, Konsentrasi Kepemilikan Dan Ukuran Perusahaan Terhadap Pengungkapan Enterprise Risk Management (Studi Empiris Pada Perusahaan Manufaktur Yang Terdaftar Di BEI Tahun 2014-2017)," Jurnal WRA 6, no. 2 (2018): 1282-1284, https://lib.unnes.ac.id/17584/.

${ }^{23}$ Shelly Armelia, "Pengaruh Ukuran Perusahaan, Profitabilitas, Likiuiditas Dan Struktur Aktifa Terhadap Struktur Modal Perusahaan Manufaktur Go Publik (Studi Sektor Kosmetik Dan Keperluan Rumah Tangga)," Jom Fisip 3, no. 2 (2016): 1-13.
} 
diaudit oleh KAP Non Big Four. Reputasi auditor menunjukkan nilai rata-rata sebesar 0,8519 atau berkisar $85,19 \%$. Hal ini menggambarkan bahwa lebih dari 50\% sampel dalam penelitian ini telah diaudit oleh KAP Big Four. Sedangkan nilai standar deviasi sebesar 0,35746 atau 35,75\% dibawah nilai rata-rata. Variabel independen risk management committee (RMC) diproksikan dengan variabel dummy yaitu nilai satu untuk perusahaan yang memiliki RMC terpisah dari komite audit dan nilai nol untuk perusahaan yang memiliki RMC tergabung dengan komite audit maupun komite lainnya. Nilai rata-rata RMC sebesar 0,6049 atau 60,49\% menunjukkan bahwa mayoritas sampel dalam penelitan ini memiliki RMC yang terpisah dari komite audit maupun komite lainnya.

Variabel independen leverage (DAR) menunjukkan nilai minimum sebesar 0,07 atau 7\% pada perusahaan Pembangungan Perumahan (Persero) Tbk, dari tahun 20162018. Sedangkan nilai maksimumnya yaitu 0,83 atau $83 \%$ pada perusahaan Bank Negara Indonesia Tbk tahun 2018. Nilai rata-rata pada variabel ini adalah sebesar 0,4283 sedangkan standar deviasinya sebesar 0,18760 .

Variabel Ukuran Perusahaan (Size) memiliki nilai minimum sebesar 29,06 yang diperoleh dari PT Surya Citra Media Tbk, yang memiliki total asset pada tahun 2016 sebesar Rp 4.820.611.941.000. Sedangkan nilai maksimum sebesar 34,33 yang diperoleh dari PT Bank Negara Indonesi Tbk, yang memiliki total asset pada tahun 2018 sebesar Rp 808.572.011.000.000. Nilai rata-rata ukuran perusahaan sebesar 31,2720 dan nilai standar deviasi ukuran perusahaan 1,17891.

Variabel depenenden enterprise risk management (ERM) memiliki nilai minimum 0,40 yang diperoleh PT Sawit Sumbermas Sarana Tbk pada tahun 2016. Nilai maksimum sebesar 0,81 yang diperoleh PT Matahari Department Store Tbk pada tahun 2018. Rata-rata untuk variabel enterprise risk management sebesar 0,6664 dengan standar deviasi 0,11028.

Tabel 2. One-Sample Kolmogorov-Smirnov Test

\begin{tabular}{ccr}
\hline & & $\begin{array}{c}\text { Unstandardized } \\
\text { Residual }\end{array}$ \\
\hline Normal Parameters & & 81 \\
& Mean & .0000000 \\
& Std. & .10050152 \\
Most Extreme & Deviation & \\
Differences & Absolute & .123 \\
Kolmogorov-Smirnov Z & .070 \\
Asymp. Sig. (2-tailed) & -.123 \\
& Positive & 1.109 \\
Output SPSS 21, 2020 & .171 \\
\hline
\end{tabular}

Tabel 2 merupakan hasil uji normalitas dengan menggunakan uji statistik non parametric kolmogrov-smirnov (K-S) menunjukkan bahwa nilai signifikansi 0,171 Hal ini menunjukkan bahwa nilai asymp sig (2-tailed) di atas 0,05 maka data residual terdistribusi secara normal.

Tabel 3. Uji Multikolinearitas

\begin{tabular}{llcl}
\hline \multicolumn{2}{c}{ Model } & \multicolumn{2}{c}{ Collinearity Statistics } \\
& Tolerance & VIF \\
\hline 1 & (Constant) &
\end{tabular}




\begin{tabular}{rll} 
KI & .120 & 8.329 \\
RA & .842 & 1.187 \\
RMC & .930 & 1.076 \\
DAR & .838 & 1.194 \\
SIZE & .120 & 8.364 \\
\hline
\end{tabular}

Sumber: Output SPSS 21, 2020.

Dari tabel 3 diatas menunjukkan bahwa semua variabel independen memiliki nilai tolerance $>0,10$ dan $\mathrm{VIF}<10$. Hasil perhitungan nilai tolerance juga menunjukkan tidak ada variabel independen yang memiliki nilai tolerance kurang dari 0,10 yang berarti tidak ada korelasi antar variabel independen. Maka dapat disimpulkan bahwa model regresi dalam penelitian ini telah terbebas dari masalah multikolinearitas.

Gambar 3. Uji Heterokedastisitas-Grafik Scatterplot

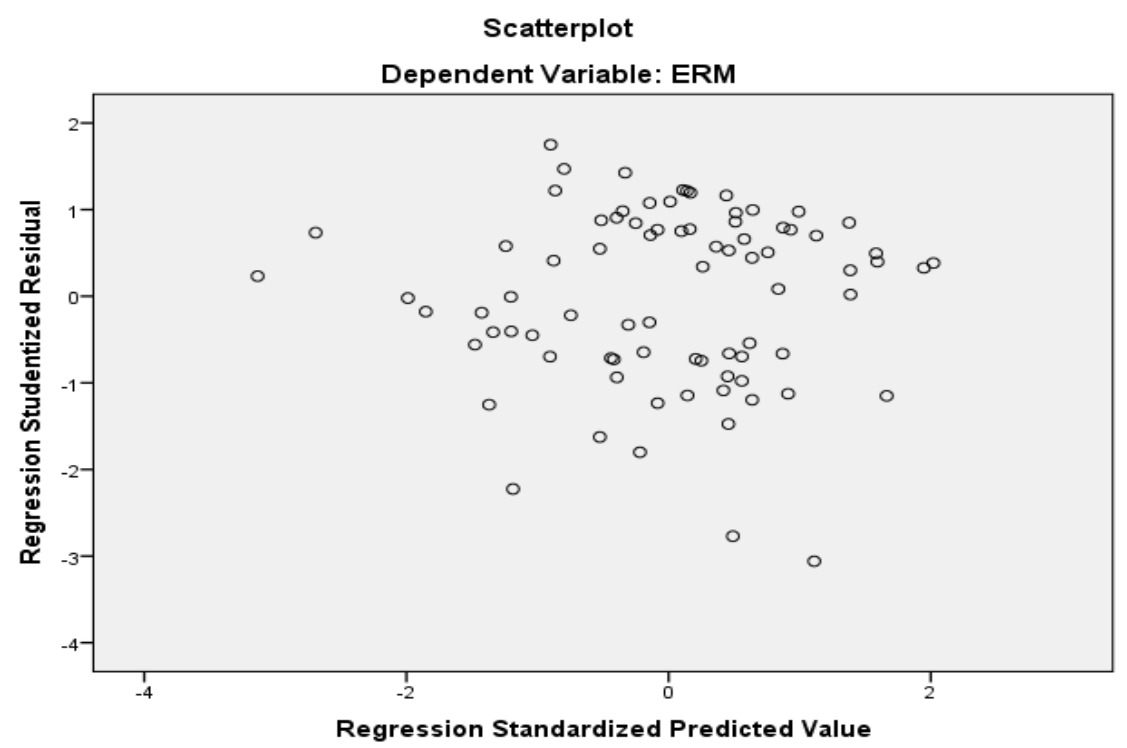

Sumber: Output SPSS 21

Gambar uji scatterplot diatas menunjukkan bahwa data sampel tersebar secara acak dan tidak membentuk suatu pola tertentu. Data tersebar baik berada di atas maupun dibawah angka 0 pada sumbu $\mathrm{Y}$. Hal ini menunjukkan tidak terdapat heterokedastisitas dalam model regresi yang digunakan sehingga layak dipakai untuk kemudian dilanjukkan ke pengujian hipotesis.

Tabel 4. Uji Autokorelasi

\begin{tabular}{lcccc}
\hline Model & $\mathrm{R}$ & $\mathrm{R}$ & Adjusted R \\
Square & Square & $\begin{array}{c}\text { Std. Error of the Durbin-Watson } \\
\text { Estimate }\end{array}$
\end{tabular}

Sumber: Output SPSS 21

Berdasarkan hasil uji pada tabel IV-5, dapat diketahui bahwa penelitian ini tidak terjadi autokorelasi. Nilai Durbin Watson diketahui sebesar 2,032 dengan jumlah sampel $8(\mathrm{n}=81)$, dengan jumlah variabel independen sebanyak 5 variabel $(\mathrm{k}=5)$. Berdasarkan tabel D-W dengan tingkat signifikansi 5\% dapat ditentukan nilai batas atas (du) adalah sebesar 1,7720. Dengan demikian, berdasarkan nilai du $<\mathrm{d}<4$-du menunjukkan bahwa nilai D-W 2,032 lebih besar dari batas atas (du) 1,7720 dan kurang dari 2,228 (4-1,7720), maka dapat disimpulkan bahwa tidak terdapat autokorelasi positif atau negatif. Tabel D-W dapat dijelaskan dengan persamaan: 


$$
\begin{gathered}
\mathrm{Du}<\mathrm{d} \quad<4-\mathrm{du} \\
1,7720<2,032<4-1,7720 \\
1,7720<2,032<2,228
\end{gathered}
$$

Tabel 5. Uji Regresi Linear Berganda

\begin{tabular}{cccccc}
\hline \multirow{2}{*}{ Model } & \multicolumn{2}{c}{$\begin{array}{c}\text { Unstandardized } \\
\text { Coefficients }\end{array}$} & \multirow{2}{*}{$\mathrm{t}$} & Sig. \\
\cline { 3 - 4 } & & $\mathrm{B}$ & Std. Error & & \\
\hline \multirow{4}{*}{1} & (Constant) & .747 & .804 & .929 & .356 \\
& KI & -.161 & .246 & -.656 & .514 \\
& RA & .096 & .035 & 2.726 & .008 \\
& RMC & .001 & .024 & .037 & .970 \\
& DAR & .143 & .068 & 2.109 & .038 \\
& SIZE & -.005 & .028 & -.177 & .860 \\
\hline
\end{tabular}

Sumber: Output SPSS 21

Dari tabel IV-6 dari persamaan regresi, maka dapat ditulis persamaan regresi sebagai berikut: ERM: 0,747 - 0,161 KI + 0,096 RA + 0,001 RMC + 0,143 DAR 0,005 SIZE.

Constant $=0,747$ (positif), artinya bila komisaris independen, reputasi auditor, risk management committee, leverage, dan ukuran perusahaan konstan atau tetap, maka enterprise risk management sebesar 0,747. Koefisien $\beta_{1}=-0,161$ (negatif), artinya setiap kenaikan $1 \%$ proporsi komisaris independen akan menurunkan luas pengungkapan enterprise risk management sebesar 0,161. Koefisien $\beta_{2}=0,096$ (positif), artinya perusahaan yang menggunakan auditor bigfour akan lebih banyak melakukan pengungkapan enterprise risk management dibandingkan dengan perusahaan yang tidak memakai jasa auditor non big four yaitu sebesar 0,096. Koefisien $\beta_{3}=0,001$ (positif), artinya perusahaan yang menggunakan risk management committee akan lebih banyak melakukan pengungkapan enterprise risk management dibandingkan dengan perusahaan yang tidak memiliki risk management committee yaitu sebesar 0,001 . Koefisien $\beta_{4}=0,143$ (positif), artinya setiap kenaikan $1 \%$ hutang akan meningkatkan luas pengungkapan enterprise risk management sebesar 0,143. Dan Koefisien $\beta_{5}=-0,002$ (negatif), artinya setiap kenaikan Rp 1 total asset akan menurunkan luas pengungkapan enterprise risk management sebesar 0,002.

Tabel 6. Tabel Uji Simultan (Uji F)

\begin{tabular}{rrrrrrr}
\hline \multirow{2}{*}{ Model } & \multicolumn{1}{c}{$\begin{array}{c}\text { Sum of } \\
\text { Squares }\end{array}$} & Df & $\begin{array}{c}\text { Mean } \\
\text { Square }\end{array}$ & F & Sig. \\
\hline \multirow{2}{*}{1} & Regression & .165 & 5 & .033 & 3.060 & $.014^{\mathrm{b}}$ \\
& Residual & .808 & 75 & .011 & & \\
& Total & .973 & 80 & & & \\
\hline
\end{tabular}

Sumber: Output SPSS 21, 2020

Berdasarkan tabel IV-7 diperoleh nilai signifikansi 0,014 dan $F_{\text {hitung }}$ sebesar 3,060. Hasil tersebut menunjukkan bahwa terdapat pengaruh simultan variabel independen terhadap variabel dependen, karena nilai signifikansi $0,014<a=0,05$. Hasil yang diperoleh menunjukan bahwa komisaris independen, reputasi auditor, risk management committee, leverage, dan ukuran perusahaan berpengaruh secara simultan terhadap enterprise risk management.

Tabel 7. Uji Parsial (Uji t)

\begin{tabular}{llrrrrr}
\hline \multirow{2}{*}{ Model } & \multicolumn{2}{c}{$\begin{array}{c}\text { Unstandardized } \\
\text { Coefficients }\end{array}$} & \multicolumn{2}{c}{$\begin{array}{c}\text { Standardized } \\
\text { Coefficients }\end{array}$} & t & \multirow{2}{*}{ Sig. } \\
\cline { 3 - 5 } & & \multicolumn{1}{c}{ B } & \multicolumn{1}{c}{ Std. Error } & Beta & & \\
\hline \multirow{2}{*}{1} & (Constant) & .747 & .804 & & .929 & .356 \\
& KI & -.161 & .246 & -.199 & -.656 & .514
\end{tabular}




\begin{tabular}{crrrrr} 
RA & .096 & .035 & .313 & 2.726 & .008 \\
RMC & .001 & .024 & .004 & .037 & .970 \\
DAR & .143 & .068 & .242 & 2.109 & .038 \\
SIZE & -.005 & .028 & -.054 & -.177 & .860 \\
\hline
\end{tabular}

Sumber: Output SPSS 21, 2020

Pengujian hipotesis pertama bertujuan untuk mengetahui pengaruh komisaris independen terhadap pengungakapan enterprise risk management. Pada penelitian ini nilai signifikansi sebesar 0,514 yang berada diatas 0,05 . Ini berarti menunjukkan bahwa komisaris independen tidak berpengaruh terhadap pengungkapan ERM pada perusahaan yang terdaftar di indeks LQ45 tahun 2016-2018, dengan demikian dapat disimpulkan bahwa $\mathbf{H}_{\mathbf{1}}$ dalam penelitian ini ditolak. Pangestuti dan Susilowati menjelaskan bahwa salah satu komisaris independen harus memiliki latar belakang pendidikan keuangan atau akuntansi, hal ini diharapkan dapat memberikan panduan bagaimana mengelola risiko. Selain itu kemungkinan pengangkatan komisaris independen oleh perusahaan hanya dilakukan untuk memenuhi regulai saja, dimana setiap perusahaan diharuskan memiliki minimal 30\% komisaris independen dalam dewan, sehingga keberadaan komisaris independen ini tidak untuk menjalankan fungsi pengawasan yang baik dan tidak menggunakan independensinya untuk mengawasi kebijakan direksi. $^{24}$

Pengujian hipotesis kedua bertujuan untuk mengetahui pengaruh reputasi auditor terhadap pengungakapan enterprise risk management. Penelitian ini menunjukan hasil nilai dengan nilai signifikansi sebesar 0,008 yang berada dibawah 0,05 . Hal ini berarti bahwa reputasi auditor memiliki pengaruh positif terhadap pengungkapan enterprise risk management (ERM), sehingga $\mathbf{H}_{2}$ dalam penelitian ini diterima. Hal ini memperlihatkan bahwa perusahaan yang menggunakan jasa auditor big four akan lebih luas dalam melakukan pengungkapan ERM daripada perusahaan yang menggunakan jasa non big four. Berdasarkan teori agensi auditor big four merupakan auditor yang dipandang memiliki reputasi baik sehingga akan mengarahkan kliennya untuk melaksanakan praktik corporate governance, membantu internal auditor dalam mengevaluasi dan meningkatkan efektivitas manajemen risiko sehingga meningkatkan kualitas penilaian dan pengawasan risiko perusahaan.

Pengujian hipotesis ketiga bertujuan untuk mengetahui pengaruh risk management committee terhadap pengungkapan enterprise risk management. Penelitian ini

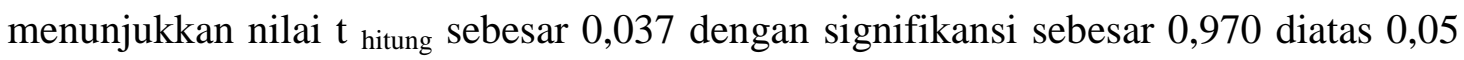
maka hal ini berarti bahwa risk management committee tidak berpengaruh terhadap pengungkapan ERM, sehingga $\mathbf{H}_{3}$ dalam penelitian ini ditolak, karena keberadaan RMC sebagai pemantau risiko belum berperan secara optimal dalam pengungkapan ERM. Dalam penelitian ini RMC pada perusahaan yang terdaftar di indeks LQ45 tidak sepenuhnya mengungkapkan ERM, dimana masih terdapat penggabungan anggota RMC dengan komite audit sehingga RMC tidak terlalu fokus kepada pengungkapan ERM.

Pengujian hipotesis keempat bertujuan untuk mengetahui pengaruh leverage terhadap pengungkapan enterprise risk management. Penelitian ini menunjukkan nilai

${ }^{24}$ Kartiko Dewi Pangestuti and Yeye Susilowati, "Komisaris Independen, Reputasi Auditor, Konsentrasi Kepemilikan , Dan Ukuran Perusahaan Terhadap Pengungkapan Enterprise Risk Management," Dinamika Akuntansi, Keuangan dan Perbankan 6, no. 2 (2017): 164-175. 
$\mathrm{t}_{\text {hitung }}$ sebesar 2,109 dengan nilai signifikansi sebesar 0,038 yang berada dibawah 0,05. Hal ini berarti bahwa leverage berpengaruh positif terhadap pengungkapan ERM, sehingga $\mathbf{H}_{4}$ dalam penelitian ini diterima. Berdasarkan stakeholder theory perusahaan dapat memberikan pengungkapan risiko agar dapat menjelaskan atas apa yang terjadi diperusahaan. Ketika perusahaan memiliki tingkat risiko hutang yang lebih tinggi dalam struktur modal, kreditur dapat memaksa perusahaan untuk mengungkapkan informasi lebih lanjut. Pihak kreditur akan selalu memantau dan membutuhkan informasi yang lebih luas mengenai kondisi keuangan perusahaan untuk meyakinkan kreditur bahwa perusahaan akan memenuhi kewajibannya pada saat jatuh tempo.

Pengujian hipotesis kelima bertujuan untuk mengetahui pengaruh ukuran perusahaan terhadap pengungkapan eneterprise risk management. Penelitian ini

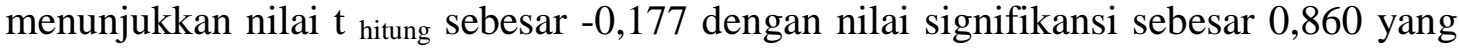
berada diatas 0,05 . Hal ini menunjukkan bahwa ukuran perusahaan tidak berpengaruh terhadap pengungkapan ERM, sehingga $\mathbf{H}_{5}$ dalam penelitian ini ditolak. Penelitian ini sejalan dengan hasil penelitian Kumalasari dan Subowo (2014), karena perusahaan yang memiliki total aset lebih besar belum tentu melakukan pengungkapan risiko yang lebih luas. ${ }^{25}$ Hal ini menunjukkan bahwa perusahaan yang memiliki total aset lebih besar belum tentu melakukan pengungkapan risiko yang lebih luas pula, karena semakin besar nilai total aset suatu perusahaan juga akan semakin luas pengungkapan yang dilakukan oleh suatu perusahaan maka semakin banyak informasi terpublikasikan yang tidak dapat digunakan oleh perusahaan pesaing dalam mencari kesempatan. Sehingga beberapa perusahaan yang memiliki total aset lebih besar melakukan pengungkapan sukarela. ${ }^{26}$

\section{Simpulan}

Penelitian ini bertujuan untuk mengetahui pengaruh komisaris independen, reputasi auditor, risk management committee, leverage dan ukuran perusahaan terhadap pengungkapan enterprise risk management. Dari lima hipotesis yang diajukan, hanya dua hipotesis yang diterima dan tiga hipotesis lainnya yang ditolak. Berdasarkan hasil penelitian didapatkan simpulan bahwa pertama, komisaris independen tidak berpengaruh terhadap Pengungkapan Enterprise Risk Management. Kedua, Reputasi uuditor dengan proksi KAP Big Four memiliki pengaruh positif terhadap pengungkapan Enterprise Risk Management. Ketiga, Risk Management Committee yang terpisah dari audit tidak berpengaruh terhadap pengungkapan enterprise risk management.keempat, Leverage dengan proksi dept to asset ratio memiliki pengaruh positif terhadap pengungkapan enterprise risk management. Dan kelima, Ukuran perusahaan dengan proksi ln total asset tidak berpengaruh terhadap pengungkapan enterprise risk managemnt.

Penelitian ini dilakukan dengan maksimal guna mencapai tujuan penelitian, akan tetapi masih terdapat beberapa keterbatasan dari Penelitian ini hanya dilakukan terhadap faktor-faktor enterprise risk management yang terdiri dari variabel komisaris independen, reputasi auditor, risk management committee, leverage dan ukuran perusahaan. Untuk

\footnotetext{
${ }^{25}$ Kumalasari, Magda dan Indah. 2014. “ Faktor-Faktor yang Berpengaruh Terhadap Luas Pengungkapan Manajemen Risiko”. Accounting Analysis Journal. Vol.3, No.1.

${ }^{26}$ Pangestuti, Kartiko Dewi dan Yeye Susilowati. 2017. "Komisaris Independen, Reputasi Auditor, Konsentrasi Kepemilikan, dan Ukuran Perusahaan Terhadap Pengungkapan Enterprise Risk Management. Dinamika Akuntansi, Keuangan dan Perbankan. Vol.4, No.1, 18-32.
} 
peneliti selanjutnya sebaiknya menambahkan variabel lain yang diduga dapat berpengaruh terhadap pengungkapan enterprise risk management. Contohnya Kepemilikan institusional dan chief risk officer. Selain itu Penelitian ini menggunakan sampel yang terdaftar di indek LQ45 berturut-turut dalam periode 2016-2018. Untuk penelitian selanjutnya perlu mempertimbangkan sampel yang lebih luas dengan menambah tahun sampel penelitian, agar data penlitian selanjutnya sehingga akan didapatkan hasil yang data lebih akurat.

Dengan adanya penelitian ini, diharapkan dapat mendorong penelitian-penelitian terkait yang lebih baik dan juga menjadi acuan bagi investor dalam pengambilan keputusan untuk berinvestasi di perusahaan yang terdaftar di Indeks LQ45. Enterprise Risk Management merupakan salah satu cara untuk memahami seberapa besar peluang dan risiko yang dihadapi. Semakin besar pengungkapan enterprise risk management maka investor semakin tertarik untuk berinvestasi. Manajemen perusahaan dapat meningkatkan enterprise risk management dengan cara mengoptimalkan fungsi-fungsi dari setiap pekerja/karyawan yang terdiri dari komisaris independen, reputasi auditor dan risk management committee tidak hanya itu juga harus mengoptimalkan keuangan dari perusahaan tersebut yang terdiri dari leverage dan ukuran perusahaan. Hal tersebut dikarenakan variabel-variabel tersebut menjadi bahan pertimbangan dalam pengambilan keputusan berinvestasi.

\section{Daftar Pustaka}

Alijoyo, Antonius, dkk. Pedoman Penerapan Manajemen Risko Berbasis Governance. Jakarta: Alijoyo, Antonius, dkk, (2012) Komite Nasional Kebijakan Governance, 2012.

Andarini, Putri, and Indira Januarti. "Hubungan Karakteristik Dewan Komisaris Dan Perusahaan Terhadap Keberadaan Komite Manajemen Risiko Pada Perusahaan Go Public Indonesia.” Jurnal Akuntansi dan Keuangan Indonesia 9, no. 1 (2012): 83-99.

Armelia, Shelly. "Pengaruh Ukuran Perusahaan, Profitabilitas, Likiuiditas Dan Struktur Aktifa Terhadap Struktur Modal Perusahaan Manufaktur Go Publik (Studi Sektor Kosmetik Dan Keperluan Rumah Tangga).” Jom Fisip 3, no. 2 (2016): 1-13.

Brigham dan Houston. Manajemen Keuangan, Edisi Kedelapan. 8th ed. Jakarta: Erlangga, 2001.

Budi Setiawan. "Pengaruh Independensi, Kualitas Audit Dan Mekanisme Corporate Governance Terhadap Integritas Laporan Keuangan Perusahaan Manufaktur Di Bursa Efek Indonesia Tahun 2008-2012.” Jom FEKON 2, no. 2 (2015): 1-15.

Committee of Sponsoring Organization of the Treadway Commission (COSO). "Internal Control- Integred Framework." Accessed October 15, 2019. https://www.coso.org/Pages/ic.aspx.

Freeman, R.F dan J, McVea. A Stakeholder Approach to Strategic Management. lose Angeles: Sage Publications, 2001.

Governance, Komite Nasional Kebijakan. Pedoman Penerapan Manajemen Risiko Berbasis Governance. Jakarta, 2011. http://www.knkg-indonesia.org/.

Indonesia, CNBC. "Market Data." Last modified 2018. Accessed October 11, 2018. https://www.cnbcindonesia.com/market-data.

Kasmir. Pengantar Manajemen Keuangan. 2nd ed. Jakarta: Prenadamedia Grup, 2016.

Pangestuti, Kartiko Dewi, and Yeye Susilowati. "Komisaris Independen, Reputasi Auditor, Konsentrasi Kepemilikan, Dan Ukuran Perusahaan Terhadap Pengungkapan Enterprise 
Risk Management." Dinamika Akuntansi, Keuangan dan Perbankan 6, no. 2 (2017): $164-175$.

Rustiarini, Ni Wayan. "Corporate Governance, Konsentrasi Kepemilikan Dan Pengungkapan Enterprise Risk Management." Journal manajemen keuangan, akuntabilitas 12, no. 2 (2012): $279-298$.

Siagian, Haidir Fitra. "Pengaruh Dan Efektivitas Penggunaan Media Sosial Sebagai Saluran Komunikasi Politik Dalam Membentuk Opini Publik.” Al-Khitabah 11 (2015): 17-26.

Verdiana, Komang, and I Utama. "Pengaruh Reputasi Auditor, Disclosure, Audit Client Tenure Pada Kemungkinan Pengungkapan Opini Audit Going Concern." E-Jurnal Akuntansi 5, no. 3 (2013): 530-543.

Widjaja Azwar. Perencanaan Sebagai Fungsi Manajemen. Jakarta: PT. Rineka Cipta., 2009.

widyawati, halwati. "Pengaruh Corporate Governance, Konsentrasi Kepemilikan Dan Ukuran Perusahaan Terhadap Pengungkapan Enterprise Risk Management (Studi Empiris Pada Perusahaan Manufaktur Yang Terdaftar Di BEI Tahun 2014-2017).” Jurnal WRA 6, no. 2 (2018): 1282-1284. https://lib.unnes.ac.id/17584/. 